\title{
ECHOVIRUS 6 ASSOCIATED TO ASEPTIC MENINGITIS OUTBREAK, IN SÃO JOAQUIM DA BARRA, SÃO PAULO, BRAZIL
}

\author{
Adriana Luchs ${ }^{1 *}$; Denise Hage Russo ${ }^{1}$; Audrey Cilli ${ }^{1}$; Fernanda Faria Costa ${ }^{1}$; Simone Guadagnucci Morillo ${ }^{1}$; \\ Bráulio Caetano Machado ${ }^{1}$; Alessandra Cristina Guedes Pellini²; Rita de Cássia Compagnoli Carmona ${ }^{1}$; \\ Maria do Carmo Sampaio Tavares Timenetsky ${ }^{1}$
}

${ }^{1}$ Laboratório de Vírus Entéricos, Instituto Adolfo Lutz, São Paulo, SP, Brasil; ${ }^{2}$ Centro de Vigilância Epidemiológica da Secretaria de Estado da Saúde, São Paulo, SP, Brasil

Submitted: June 15, 2007; Returned to authors for corrections: September 22, 2007; Approved: January 20, 2008.

\begin{abstract}
An aseptic meningitis outbreak occurred during a period from February to May 2004 in São Joaquim da Barra, a town in the northern region of São Paulo State. A total of 40 cases were reported to the Epidemiological Surveillance Center of São Paulo State. Cerebrospinal fluid samples obtained from 23 patients were sent to the Adolfo Lutz Institute for isolation of the virus. These samples were inoculated into RD, HEp2 and Vero cell lineages and those presenting a cytopathogenic effect were selected for analysis by indirect immunofluorescence assay (IFA), neutralization testing (Nt) and reverse transcriptase-polymerase chain reaction (RT-PCR). Cytopathogenic effects were observed in 52.2\% (12/23) of these samples. All isolated viruses were identified as human enterovirus by IFA and RT-PCR and echovirus 6 was typed by IFA and Nt. Our results confirmed the participation and importance of echovirus as the etiological agent responsible for this outbreak and the serotype diversity of human enteroviruses circulating in São Paulo State.
\end{abstract}

Key words: Enterovirus surveillance; echovirus 6; aseptic meningitis

Picornaviruses are a diverse group of viral pathogens and are one of the most common causes of human infections worldwide. The family Picornaviridae comprises nine genera: Enterovirus, Rhinovirus, Cardiovirus, Aphthovirus, Hepatovirus, Parechovirus, Erbovirus, Kobuvirus, and Teschovirus. Within the Picornaviridae family, there are six wellknown genera of human pathogens: Rhinovirus, human Enterovirus (HEV), Hepatovirus, Parechovirus, Cardiovirus and Kobuvirus. The Enterovirus genus consists of 65 human serotypes, which have been classified into five species: Poliovirus and HEV-A to -D $(18,28)$.

HEV outbreaks mainly occur during summer and autumn, but sporadic infections might be observed throughout the year. HEV are acquired by fecal-oral contamination and, less commonly, are spread by respiratory droplets. These viruses are responsible for a series of clinical manifestations affecting many organs of the body. When present, clinical disease ranges from minor undifferentiated febrile illnesses to severe and permanent, sometimes fatal, paralysis. Many Enterovirus infections are asymptomatic. By far the most important clinical syndromes caused by HEV are those due to infection of the central nervous system, liver, lungs and heart (24). Clinical syndromes such as poliomyelitis, meningitis, pleurodynia, herpangina, conjunctivitis, and hand-foot-and-mouth, respiratory, and gastrointestinal diseases are frequently associated with HEV (15). In addition, encephalitis, myocarditis and neonatal enteroviral sepsis might be related to the development of some chronic diseases (e.g., type I diabetes and dilated cardiomyopathy) (10).

Meningitis is a disease characterized by inflammation of the tissues that cover the brain and spinal cord. The most common symptoms are fever, severe headache, neck stiffness, photophobia, drowsiness or confusion, nausea and vomiting. Viral meningitis or aseptic meningitis (AM) is a serious but

*Corresponding Author. Mailing address: Instituto Adolfo Lutz, Virologia, $2^{\circ}$ andar, Laboratório de Vírus Entéricos. Avenida Dr. Arnaldo, $\mathrm{n}^{\circ} 355$ - CEP: 01246-902, São Paulo/SP, Brasil. E-mail: driluchs@usp.br 
rarely fatal disease in individuals with a normal immune system. This disease occurs sporadically or in outbreaks, and more than $90 \%$ of cases are associated with HEV (3).

Members of the HEV-B species are the most common causes of AM. These species include the six serotypes of group B coxsackievirus (CV-B), echovirus (E), coxsackievirus A9 (CVA9), enterovirus 69 (HEV-69), and the recently characterized enterovirus 73 (HEV-73). The predominant E serotypes vary from year to year, with E-30, E-13 and E-18 being the serotypes most frequently isolated over the past few years in Europe and the United States (29).

At the beginning of the 1980s, Javirs and Tucker (9) reported one case of AM caused by E-7 in young children. During the surveillance of viral infections of the central nervous system in Finland in late 1985, E-5 was recognized as the most important etiological agent of an AM outbreak (11). In a period from 1999 to 2002, E-30, E-13, E-18 and E-6 have been identified most frequently in Europe and the United States (29). In the United States, E-18 and E-13 were the predominant serotypes between 2000-2001, followed by CV-B5, CV-B2 and E-6 (3). E-9 was the predominant HEV serotype identified in the eastern United States in 2003 (5), and E-9 and E-30 have been frequently associated with AM outbreaks (4). In Brazil, E-30 has been the most prevalent etiological agent of viral meningitis, causing both outbreaks and sporadic cases $(7,14)$.

Monitoring circulating Enterovirus is important because individual serotypes can be associated with different clinical manifestations and outcomes, and show different temporal patterns of circulation. Changes in predominant serotypes can be accompanied by large-scale outbreaks of enteroviral illnesses. In Brazil, complete studies including epidemiological data provided by the health surveillance systems and laboratory investigation of HEV serotypes as causal agent of AM cases are scarce.

In the present study we characterized HEV isolated during an AM outbreak that occurred in a period from February to May 2004 (7th to 17th epidemiological week) in São Joaquim da Barra, a town in the northern region of São Paulo State, with a population of 40,000 inhabitants. During this period, a total of 40 cases of AM affecting all age groups were notified to the Epidemiological Surveillance Center of São Paulo State (CVE). The CVE data indicated a person-to-person transmission with a short incubation period based on symptoms and the presence of cerebrospinal fluid (CSF) leukocytosis. An increase in leukocyte numbers is typically observed in viral meningitis, with lymphocytic pleocytosis of less than 1,000 cells $/ \mathrm{mm}^{3}$, although counts as high as 2,000 cells $/ \mathrm{mm}^{3}$ might be present. In these samples, cellularity ranges from 6 to $3,242 \mathrm{cells} / \mathrm{mm}^{3}$, with a mean of 328.5 cells $/ \mathrm{mm}^{3}$, a feature compatible with a suspicion of viral etiology.

Viral meningitis affects different ages, especially children between 5 and 10 years of age, but is rare in individuals over the age of 40 . The disease is generally benign and resolves within a few days (4). In the present study, the age of the patients ranged from 0 to 50 years, with a mean of 7.8 years and a median of 4.5 years. Children aged 1 to 4 years were the most affected (incidence rate of 65.0 per 10,000 inhabitants), followed by those aged 5 to 9 years (incidence rate of 33.0 per 10,000 inhabitants). Common clinical symptoms included fever (97.5\%), vomiting (95.0\%), and neck stiffness (90.0\%). Protein levels ranged from 15.0 to $72.0 \mathrm{mg} / \mathrm{dL}$, with a mean of $37.9 \mathrm{~g} / \mathrm{dL}$, and CSF glucose concentrations ranged from 37 to $50.4 \mathrm{mg} / \mathrm{dL}$, with a mean of $56.9 \mathrm{mg} / \mathrm{dL}$. The patients studied regularly attended daycare centers and elementary schools. No death or sequelae were reported, although the average hospital stay could not be calculated.

CSF samples were collected for cytochemical tests. Twentythree samples were aliquoted, immediately frozen at $-70^{\circ} \mathrm{C}$ and sent to the Adolfo Lutz Institute for diagnostic evaluation. All CSF samples were inoculated directly into three cell lineages: RD (human rhabdomyosarcoma cells, ATCC-CCL-136), HEp2 (human larynx carcinoma cells, ATCC-CCL-23) and Vero (African green monkey kidney cells, ATCC-CCL-81). The samples were inoculated in duplicate using a minimum of 0.1 and $0.2 \mathrm{~mL} \mathrm{CSF}$ and incubated at $36^{\circ} \mathrm{C}$. The tubes were observed daily for a period of 4 weeks (16). When a cytopathogenic effect was observed, the samples were analyzed by the reverse transcriptase-polymerase chain reaction (RT-PCR), indirect immunofluorescence assay (IFA) and neutralization testing (Nt); in the absence of a cytopathogenic effect, subsequent passages were performed.

Viral RNA was extracted from the virus isolated in cell culture with Trizol ${ }^{\circledR}$ LS reagent (Invitrogen, Carlsbad, CA, USA) and chloroform according to manufacturer instructions. The amplification reactions were carried out in a Gene Amp PCR System 9600 Perkin Elmer thermocycler (Perkin-Elmer Corporation, Norwalk, CT, USA). The PCR products were separated on $1.5 \%$ agarose gel stained with ethidium bromide. The primers directed at the 5'-nontranslated region amplify a product of $437 \mathrm{bp}$ which can be used for characterization of the HEV genus $(23,30)$. For confirmation of the genus and for identification of the group and HEV serotypes, samples causing a cytopathic effect of at least $75 \%$ in cell cultures were submitted to IFA using commercially available specific monoclonal antibodies (Chemicon International Inc., Temecula, CA, USA) (2).

Serotyping was carried out by a neutralization method using intersecting pools of antisera A to H (Statens Serum Institut, Copenhagen, Denmark) against the pre-titrated virus (20) according to the Lim Benyesh-Melnick scheme (13) for identification (17). Individual type-specific antisera against CVB3 obtained from the National Institute of Allergy and Infectious Diseases (NIAID), was also included.

In the present study, $56.5 \%$ (12/23) of the samples caused a cytopathogenic effect in the RD cell lineage 4 to 7 days after inoculation. All isolated samples were identified as Enterovirus 
by RT-PCR. A bright apple-green fluorescence was observed in the IFA, indicating a positive reaction to the Enterovirus genus and to the echovirus 6 serotype. IFA was negative for the other monoclonal antibodies. The use of cell cultures permits replication of viral particles and increases viral mass, thus allowing serotyping by IFA and Nt. The pools of antisera $\mathrm{C}$ and $\mathrm{D}$ (13) neutralized viral infectivity, confirming the identification of echovirus 6 serotype. IFA and Nt have been used to provide epidemiological data about the circulation of Enterovirus and the etiological profile of AM in Brazil.

Echovirus has been described as the major HEV associated with cases of AM (10) and is detected in about $50 \%$ of $\mathrm{HEV}$ infections. Other types of viral meningitis do not induce any particular clinical signs that indicate HEV disease (25).

Since the past decade, the number of studies regarding AM associated with HEV has markedly increased worldwide (8). The most prevalent HEV serotypes found in several epidemiological studies conducted between 1992 and 2006 were E-9 and E-6 in Australia (1), E-6 in the United States (3,26), E-30, E-13, E-18, E-6, CV-B5 and E-11 in Belgium (29), E-6, E-13 and E30 in the French Rhone Alps (6), E-6 in Cyprus, and E-30 and E6 in Madrid $(21,22)$. This scenario confirms E-6 as the fifth most commonly identified $\mathrm{HEV}$, which appeared in $62 \%$ of reports of known serotypes in a surveillance study conducted in the US, with three major outbreaks of activity in 1970-1977, 1985-1990, and 1994-2000, followed by a further increase in 2005. During periods of high activity, E-6 is often associated with outbreaks, such as community outbreaks of AM or outbreaks in neonatal nurseries (10). These findings agree with our results showing high activity of E-6 associated with an AM outbreak in São Joaquim da Barra that occurred in early 2004.

Recent Brazilian epidemiological studies regarding AM have identified E-1, E-4, E-9, E-13, E-18, E-25 and E-30, CV-B2, CV-B3, CV-B5, CV-B6, and HEV-71 as the most common serotypes (7, 12, 14, 27). In a study conducted between 1998 and 2003, Santos et al. (7) detected E-6 associated with AM only in sporadic cases. Prior to the present study, no evidence of E-6 involved in AM outbreaks in Brazil has been reported.

In Brazil, 11,500 cases per year with suspected viral etiology are notified, but in most cases the etiological agent is not identified (19). Recently, the National Surveillance System for Viral Meningitis was introduced by the Ministry of Health, which will help improve the sensitivity of surveillance systems for the detection and diagnosis of viral meningitis and provide information about the disease. The Enteric Virus Laboratory of the Adolfo Lutz Institute participates in this program by performing the laboratory diagnosis of Enterovirus and by disseminating etiological data.

Our results confirmed the participation and importance of echovirus as the etiological agent responsible for this AM outbreak and the serotype diversity of Echovirus circulating in São Paulo State.

\section{ACKNOWLEDGMENTS}

We would like to thank the staff of the Cellular Cultures Section of Adolfo Lutz Institute for providing the cells used in this study; Division of Respiratory Virus of State Surveillance Center for epidemiological data support; Daniela Bernardes Borges for the laboratory assistance; and Kerstin Markendorf for editorial assistance.

\section{RESUMO}

\section{Echovirus 6 associado a surto de meningite asséptica em São Joaquim da Barra, São Paulo, Brasil}

Entre fevereiro e maio de 2004, em São Joaquim da Barra, Estado de São Paulo, foi notificado ao Centro de Vigilância Epidemiológica (CVE) um surto de meningite asséptica (MA) envolvendo 40 indivíduos. Foram enviadas ao Instituto Adolfo Lutz amostras de líquido cefalorraquidiano (LCR) de 23 pacientes com MA para tentativa de isolamento viral. Estas amostras foram inoculadas em 3 linhagens celulares: RD, HEp2 e Vero. Culturas celulares que apresentaram efeito citopático (ECP) foram submetidas a ensaio de Imunofluorescência Indireta (IFI), reação de Neutralização (Nt) e RT-PCR (Transcrição Reversa - Reação em Cadeia da Polimerase). Em 52,2\% (12/23) das amostras foi observado ECP. Todos os vírus isolados foram identificados como gênero HEV por IFI e RT-PCR e o sorotipo echovirus 6 (E6) por IFI e Nt. Nossos resultados confirmam a participação e importância dos echovirus como agente etiológico responsável pelo surto ocorrido e a diversidade de sorotipos circulantes no Estado de São Paulo.

Palavras-chave: vigilância de Enterovirus; echovirus 6; meningite asséptica

\section{REFERENCES}

1. Ashwell, M.J.; Smith, D.W.; Phillips, P.A.; Rouseil. (1996). Viral meninigitis due to echovirus types 6 and 9: epidemiological data from Western Australia. Epidemiol. Infect., 117 (3), 507-512.

2. Bastis, D.S.; Simonet, S.; Patterson, M.A.; Neill, S. (1995). Identifications of Enteroviruses by indirect immunofluorescence using monoclonal antibodies. Clin. Diagn. Virol., 3, 83-93.

3. CDC - Centers for Disease Control and Prevention. (2002). Enterovirus surveillance - United States, 2000 - 2001. MMWR Morb. Mortal. Wkly. Rep., 51 (46), 1047-1049.

4. CDC - Centers for Disease Control and Prevention. (2003). Outbreaks of aseptic meningitis associated with echoviruses 9 and 30 and preliminary surveillance reports on Enterovirus activity - United States. MMWR Morb. Mortal. Wkly. Rep., 52 (32), 761-764.

5. CDC - Centers for Disease Control and Prevention. (2004). Aseptic meningitis outbreak with echovirus 9 among creational vehicle campers - Connecticut, 2003. MMWR Morb. Mortal. Wkly. Rep., 53 (31), 710-713.

6. Chomel, J.J.; Antona, D.; Thouvenot, D.; Lina, B. (2003). Three ECHOvirus serotypes responsible for outbreak of aseptic meningitis 
Rhone - Alpes region, France. Eur. J. Clin. Microbiol. Infec. Dis., 22 (3), 191-193.

7. Dos Santos, G.P.; Skraba, I.; Oliveira, D.; Lima, A.A.; Melo, M.M.; Kmetzsch, C.I.; Costa, E.V.; Silva, E.E. (2006). Enterovirus meningitis in Brazil, 1998-2003. J. Med. Virol., 78 (1), 98-104.

8. Gomes, M.L.C.; Kopecka, H.; Linhares, A.C. (2001). Detection of Enteroviruses in cases of neurological disorders in the state of Pará, Brazil. Rev. Inst. Med. Trop., 43 (6), 321-324.

9. Jarvis, W.R.; Tucker, G. (1981). Echovirus type 7 meningitis in young children. Amer. J. Dis. Child., 135, 1009-1012.

10. Khetsuriane, N.; LaMonte-Fowlkes, A.; Oberste, M.S.; Pallansch, M.A. (2006). Enterovirus Surveillance - United States 1970-2005. MMWR Morb. Mortal. Wkly. Rep., 52 (SS08), 1-20.

11. Kinnunen, E.; Hovi, T.; Stenvik, M.; Hellstron, O.; Porras, J.; Kleemola, M.; Kantanen, M.L. (1987). Localized outbreak of enteroviral meningitis in adults. Acta Neurol. Scand., 75, 346-351.

12. Lamarão, L.M.; Gomes, M.L.C.; Ferreira, L.L.A.; Fonseca, C.M.; Araújo, L.C.B.; Santana, M.B.; Tavares-Neto, J. (2005). Pesquisa de Enterovirus em casos de Síndrome de Meningite Asséptica de Belém - PA. Rev. Soc. Bras. Med. Trop., 38 (5), 391-395.

13. Lim, K.A.; Benyesh-Melnick, M. (1960). Typing of viruses by combination of antiserum pools. Application to typing of enteroviruses (coxsackie and echo). J. Immunol. 84, 309-317.

14. Machado, B.C.; Ferreira, R.S.; Carmona, R.C.C; Timenetsky, M.C.S.T. (2007). Aseptic meningitis outbreak of echovirus 30 in São Paulo State, Brazil. Braz. J. Microbiol., 38, 97-102.

15. Melnick, J.L. (1996). Enteroviruses: polioviruses, coxsackieviruses, echoviruses and newer Enteroviruses. In: Fields, B.N.; Knipe, D.M. Howley, P.M.; Chanlock, R.M.; Melnick, J.L.; Monath, T.P. (eds) Field's virology. 3rd ed. Lippincott-Raven Publishers, Philadelphia, USA, p. 655-712

16. Melnick, J.L.; Werner, H.A.; Phillips, C.A. (1979). Enteroviruses. In: Lennette E.H., Schimidt N.J. (eds). Diagnostic procedures for viral of rickettsial diseases. 3rd ed. American Public Health Association, Washington, D.C., USA. p.471-534.

17. Melnick, J.L.; Wimberly, I.L. (1985). Lyophilized combination pools of Enterovirus equine antisera: new LBM pools prepared from reserves of antisera stored frozen for two decades. Bull. W.H.O., 63, 543-550.

18. Oberste, M.S.; Maher, K.; Williams, A.J.; Dybdahl-Sissoko, N.; Brown, B.A.; Gookin, M.S.; Peñaranda, S.; Mishrik, N.; Uddin, M.; Pallansch, M.A. (2006). Species-specific RT-PCR amplification of human enteroviruses: a tool for rapid species identification of uncharacterized enteroviruses. J. Gen. Virol., 87: 119-128.

19. Peres, L.V.C.; Carvalhanas, T.R.M.P.; Barbosa, H.A.; Gonçalves, M.I.C.; Timenestky, M.C.S.T.; Campéas, A.E. Meningite Viral.
(2006). BEPA Boletim Epidemiológico Paulista. http://www.cve. saude.sp.gov.br/agencia/bepa30_menviral.htm

20. Reed, L.J.; Muench, H. (1938). A simple method of estimating fifty per cent endpoints. Am. J. Hyg., 27, 493-497.

21. Richter, J.; Koptides, D.; Tryfonos, C.; Christodoulou, C. (2006). Molecular typing of enteroviruses associated with viral meningitis in Cyprus, 2000-2002. J. Med. Microbiol., 55 (pt 8), 1035-1041.

22. Rodríguez, M.A.G.; Comas, L.G.; Garduño, I.R.; Fernández, C.G.; Gavín, M.O.; Fernández, R.R. (2006). Increase viral meninigitis cases reported in the Autonomous Region of Madrid, Spain, 2006. Euro. Surveill., 11 (11), E061103.3.

23. Rotbart, H.A. (1990). Enzymatic RNA amplification of the Enteroviruses. J. Clin. Microbiol., 28, 438-442.

24. Rotbart, H.A.; Hayden, F.G. (2000). Picornavirus infections: a primer for the practitioner. Arch. Fam. Med., 9, 913-920.

25. Schumacher, J.D.; Chuard, C.; Renevey, F.; Matter, L.; Regamey, C. (1999). Outbreak of Echovirus 30 Meningitis in Switzerland. Scand. J. Infect. Dis., 31, 539-542.

26. Sedmak, G.; Bina, B.; Mcdonald, J. (2003). Assessment of an Enterovirus sewage surveillance system by comparison of clinical isolates with sewage isolates from Milwaukee, Wisconsin, collected August 1994 to December 2002. App. Envir. Microbiol., 69 (12), 7181-7187.

27. Silva, H.R.; Tanajura, G.M.; Tavares-Neto, J.; Gomes, M.LC.; Linhares, A.C.; Vasconcelos, P.F.C.; Ko, A.I. (2002). Aseptic meningitis syndrome due to Enterovirus and Leptospira $s p$ in children of Salvador, Bahia. Rev. Soc. Bras. Med. Trop., 35 (2), 159-165.

28. Stanway, G.; Brown, F.; Christian, P.; Hovi, T.; Hyypiä, T.; King, A.M.Q.; Knowles, N.J.; Lemon, S.M.; Minor, P.D.; Pallansch, M.A.; Palmenberg, A.C.; Skern, T. (2005). Family Picornaviridae. In: Fauquet, C.M.; Mayo, M.A.; Maniloff, J.; Desselberger, U.; Ball, L.A. (eds). Virus taxonomy-classification and nomenclature of viruses. $8^{\text {th }}$ report of the International Committee on the Taxonomy of Viruses. Amsterdam, The Netherlands: Elsevier Academic Press. p.757-778.

29. Thoelen, I.; Moes, E.; Lemey, P.; Mostmans, S.; Wollants, E,; Lindberg, A.M.; Vandamme, A.M.; Van Ranst, M. (2004). Analysis of the serotype and genotype correlation of VP1 and the 5'noncoding region in an epidemiological survey of the human Enterovirus B species. J. Clin. Microbiol., 42 (3), 963-971.

30. Zoll, G.J.; Melchers, W.J.; Kopecka, H.; Jambroes, G.; van der Poel, H.J.; Galama, J.M. (1992). General primer-mediated polymerase chain reaction for detection of enteroviruses: application for diagnostic routine and persistent infections. J. Clin. Microbiol., 30 (1), 160-165. 